\title{
An estimate of the nutrients utilized for pregnancy by Merino sheep
}

\author{
By J. P. LANGLANDS AND H. A. M. SUTHERLAND \\ C.S.I.R.O., Pastoral Research Laboratory, Armidale, NSW, Australia
}

(Received I September I967-Accepted 18 December 1967)

\begin{abstract}
I. Fifty-one pregnant fine-wool Merino ewes were slaughtered at intervals during pregnancy. The gravid uteri were dissected and were separated into uterus, membrane and fluid, and foetus fractions, which were analysed separately for water, nitrogen, ash, fat, calcium, phosphorus, sodium and potassium content.

2. Uteri from twenty-one similar non-pregnant ewes were also analysed for these constituents.

3. A number of relationships between the composition of the gravid uterus minus the composition of the uterus taken from non-pregnant sheep, and time from conception were calculated.

4. The rate of nutrient deposition was calculated from these relationships and estimates were made of the nutrients utilized for pregnancy.
\end{abstract}

Nutrients utilized for pregnancy can be calculated from estimates of nutrient retention in the gravid uterus and from estimates of the availability of the nutrients in the diet (Agricultural Research Council, I965). Cloete (1939) and Wallace (1948) have described the development of the ovine foetus in terms of fresh weight and of the weight of different tissues, but little information is available on chemical composition. As a result, the estimates given by the Agricultural Research Council (1965) for the composition of the ovine foetus were derived from analyses of the lamb at birth or from analyses of cattle foetuses. The chemical composition of the uterine contents of pregnant cattle was determined by Jakobsen (1957) and of pregnant swine by Mitchell, Carroll, Hamilton \& Hunt (I93 I).

Many relationships have been used to describe foetal growth. Jakobsen (1957) favoured the exponential relationship, $y=a e^{b t}$ where $y$ is the energy or nitrogen deposited in the conceptus, $t$ is time from conception and $a$ and $b$ are constants; Mitchell et al. (I93I) preferred the allometric equation, $y=a t^{b}$. MacDowell \& Allen (1927) found that the allometric equation gave a better description of the growth rate of mouse embryos when the time scale was taken from 7 days after conception, and Mitchell (I962) adopted similar equations for describing the growth of human and bovine foetuses.

In the study reported here sheep were slaughtered at intervals during pregnancy. The uterus, foetus, and foetal membranes were dissected out and their chemical composition was determined. Relationships between chemical composition and time from conception were calculated and estimates of the rate of deposition of nutrients were derived from these equations. 
EXPERIMENTAL

Sheep

Seventy-two fine-wool Merino ewes aged between 7 and 8 years and with a mean live weight of $3^{6.7} \mathrm{~kg}$ grazed a perennial ryegrass-white clover pasture and received lucerne hay and wheat mixed with I \% ground limestone as supplementary feed throughout pregnancy. Fine-wool Merino rams carrying coloured crayons on their briskets (Radford, Watson \& Wood, I960) ran with the ewes for I6 days. The ewes were inspected daily and those marked with crayon were assumed to have been served, and were temporarily transferred to a different pasture. After 16 days the rams were withdrawn and all the ewes were returned to the original pasture which they grazed throughout pregnancy.

At intervals of approximately to days the ewes were weighed and a random sample was slaughtered. The weight of the conceptus was deducted from the live weight. On average the non-pregnant ewes gained $0.04 \mathrm{Ig}$ per day and the pregnant ewes maintained constant live weights. All pregnant ewes carried a single foetus. Twenty-one non-pregnant ewes and fifty-one pregnant ewes were slaughtered for this study. One ewe was slaughtered when less than 30 days pregnant, twenty-two between $3 \mathrm{I}$ and 60 days, six between 61 and 90 days, eleven between $9 \mathrm{I}$ and 120 days, and eleven between 121 and 145 days.

At slaughter the reproductive tract was severed at the junction of the cervix and vagina, and the tract was dissected into foetus, membranes and associated fluids, and uterus. These were weighed immediately and were stored at $-5^{\circ}$ until analysed.

\section{Analytical}

Membranes, uteri and foetuses were dried to constant weight in a forced-draught oven set at $100^{\circ}$. It was necessary to lacerate the tissues to ensure uniform and rapid drying. The dried tissues were weighed and milled in a laboratory mill fitted with a I $\mathrm{mm}$ sieve. There was insufficient foetal material for individual analyses in the early stages of pregnancy and the dried foetuses were combined for six, four, eight and five sheep slaughtered when less than 35 days pregnant, $36-42$ days, $43^{-48}$ days and $49-56$ days pregnant, respectively.

Losses in drying were less than $\mathrm{I} \%$ of the $\mathrm{N}$ present, which was estimated on the dried material by a semi-micro-Kjeldahl procedure in which selenium was used as a catalyst. All $\mathrm{N}$ analyses were standardized with hippuric acid. The dried material was ashed at $590^{\circ}$ for $\mathrm{I} 6 \mathrm{~h}$ for the determination of ash and organic matter. Fat was extracted with di-isopropyl ether from dried material in a Soxhlet apparatus. The energy content of six samples of fat and fat-free organic matter was measured in an adiabatic bomb calorimeter. The mean calorific values of fat from membranes, foetuses and uteri were $9 \cdot 16 \pm 0.003,9.26 \pm 0.03 \mathrm{I}$ and $9.39 \pm 0.005 \mathrm{kcal}$ per $\mathrm{g}$ respectively and the corresponding values for the fat-free fraction were $5.26 \pm 0.003$, $5 \cdot 35 \pm 0.054$ and $5 \cdot 28 \pm 0.005 \mathrm{kcal}$ per $\mathrm{g}$ organic matter. These factors were used to calculate the energy content of the different tissues. 
Calcium was determined by atomic absorption spectroscopy on ashed samples. Approximately $25 \mathrm{mg}$ ash were dissolved in $5 \mathrm{ml}$ concentrated hydrochloric acid and the digest was made up to $100 \mathrm{ml}$ with glass-distilled water containing I.5 g strontium chloride/l. Ca was determined at $4227 \AA$ using an air-acetylene flame. As a check on analytical procedures a number of samples were analysed for $\mathrm{Ca}$ by an oxalate-permanganate method. The mean difference between the methods expressed as a percentage of the mean concentration of $\mathrm{Ca}$ was $0.22 \pm 0.39 \%$.

Sodium and potassium were estimated by flame photometry. Approximately $0.25 \mathrm{~g}$ dried tissue was digested in $25 \mathrm{ml}$ of a nitric-sulphuric acid mixture $(3: 1, v / v)$ and the digest was made up to $100 \mathrm{ml}$ with deionized water. The samples were read in a flame photometer using an oxygen-propane flame with lithium as an internal standard. Digestion mixture, $\mathrm{P}, \mathrm{Ca}$ and $\mathrm{Na}$ or $\mathrm{K}$ were added to the standard solutions in appropriate concentrations to minimize differential interference by these elements. $\mathrm{P}$ was estimated on the same digest by the method of Fogg \& Wilkinson (1958). On several occasions known quantities of $\mathrm{K}, \mathrm{P}$ and $\mathrm{Na}$ were added to samples which were then re-analysed. At no time was less than $98.5 \%$ of the additional $\mathrm{Na}, \mathrm{K}$ or $\mathrm{P}$ recovered.

\section{RESULTS}

The mean composition of the uteri from the twenty-one non-pregnant sheep is given in Table $\mathbf{I}$. The values were deducted from the corresponding values for the uteri of pregnant sheep and a series of equations was calculated relating the composi-

Table I. Mean composition of twenty-one uteri from non-pregnant Merino ezves

$\begin{array}{lcl}\text { Component } & \text { Mean } & \begin{array}{l}\text { Standard } \\ \text { deviation }\end{array} \\ \text { Fresh wt (g) } & 62.5 & \pm 3.2 \\ \text { Dry wt (g) } & 1 \mathrm{I} .3 & \pm \mathrm{I} .6 \\ \text { Ash (g) } & 0.69 & \pm 0.15 \\ \text { Fat (g) } & 0.59 & \pm 0.3 \mathrm{I} \\ \text { Energy (kcal) } & 66.4 & \pm 4.2 \\ \text { Nitrogen (g) } & \mathrm{I} .75 & \pm 0.10 \\ \text { Calcium (g) } & 0.0070 & \pm 0.0030 \\ \text { Phosphorus (g) } & 0.094 & \pm 0.016 \\ \text { Sodium (g) } & 0.14 & \pm 0.03 \\ \text { Potassium (g) } & 0.13 & \pm 0.03\end{array}$

tion of the gravid uterus or of its components to time $(x)$ from mating measured in days. The models fitted were:

(a) Uterus, membranes and foetus separately $(y)$

$$
\begin{aligned}
& y=a+b x+c x^{2}+d x^{3}+e x^{4}, \\
& y=f x+g x^{2}+h x^{3} .
\end{aligned}
$$


(b) Total products of conception $(Z)$

$$
\begin{aligned}
& Z=i+j x+k x^{2}+l x^{3}+m x^{4} \\
& Z=n x+o x^{2}+p x^{3} \\
& Z=q x^{r} \\
& Z=s(x+t)^{u} .
\end{aligned}
$$

Models (I) to (4) were calculated by standard procedures and the regression coefficient for the highest power of $x$ was tested for significance. When the coefficient was not significant at the $5 \%$ probability level, this term was deleted from the model and the equation was recalculated. This procedure was repeated until the regression coefficient for the highest power of $x$ was significant. The coefficient $r$ in model (5) was estimated by regression analysis of $\log Z$ on $\log x$. The value of $q$ was obtained by relating $Z$ to $x^{r}$ by standard regression procedures. A similar method was adopted for fitting model (6) after values of $(x+t)$ had been calculated by taking trial values of $t$ between +49 and -23 days. Within this range the residual standard deviation took a minimum value and the corresponding values of $s$ and $u$ were adopted for model (6).

The approximate residual standard deviations for the different equations are given in Table 2. Models ( $\mathrm{I}$ ) and (2), and (3) and (4) fitted the values equally well, but since models (2) and (4) passed through the origin they were considered more acceptable on biological grounds.

The partial regression coefficients for equations calculated with models (I) and (3) may be obtained from the authors. Those for models (4), (5) and (6) are given in Table 3. The coefficients derived with model (2) are given in Table 4.

The estimated rate of nutrient storage is affected by the choice of model used to describe the growth of the conceptus. Model (6) has been used for subsequent calculations since it was the most precise and since a number of the polynomial relationships give negative values for $Z$ in the early stages of pregnancy. The composition of the gravid uterus and the rate of nutrient deposition at various stages of pregnancy have been calculated from equations derived with model (6) and the values are given in Table 5.

Values predicted by equations based on model (2) for the composition of the foetus, uterus and membranes are given in Table 6. Since the values are predicted from three separate relationships calculated independently, the sum of the three predicted values may differ from the corresponding values for the gravid uterus calculated with model (4) or from those given in Table 5.

Energy requirements for pregnancy can be estimated from the results obtained in this study and from the calorimetric studies of Graham (1964a), which were made with pregnant Merino ewes which gave birth to lambs similar in size to those in the present study. The maintenance requirements of ewes numbered 2I and 23 in Graham's study if not pregnant were estimated to be 1198 and I $108 \mathrm{kcal}$ metabolizable energy per day respectively on the assumptions derived from his data that (I) their live weights excluding the conceptuses were $4^{\circ}$ and $37 \mathrm{~kg}$ respectively, (2) their fasting heat out- 
Vol. 22

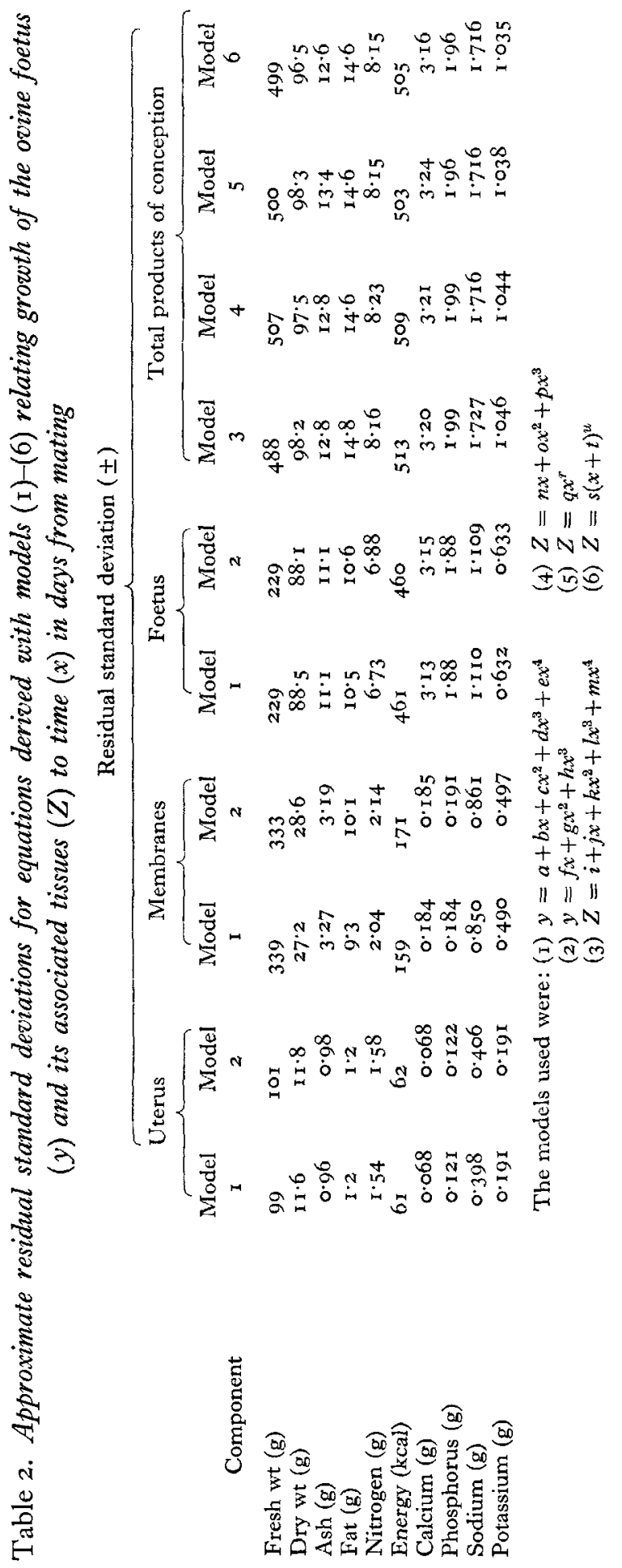



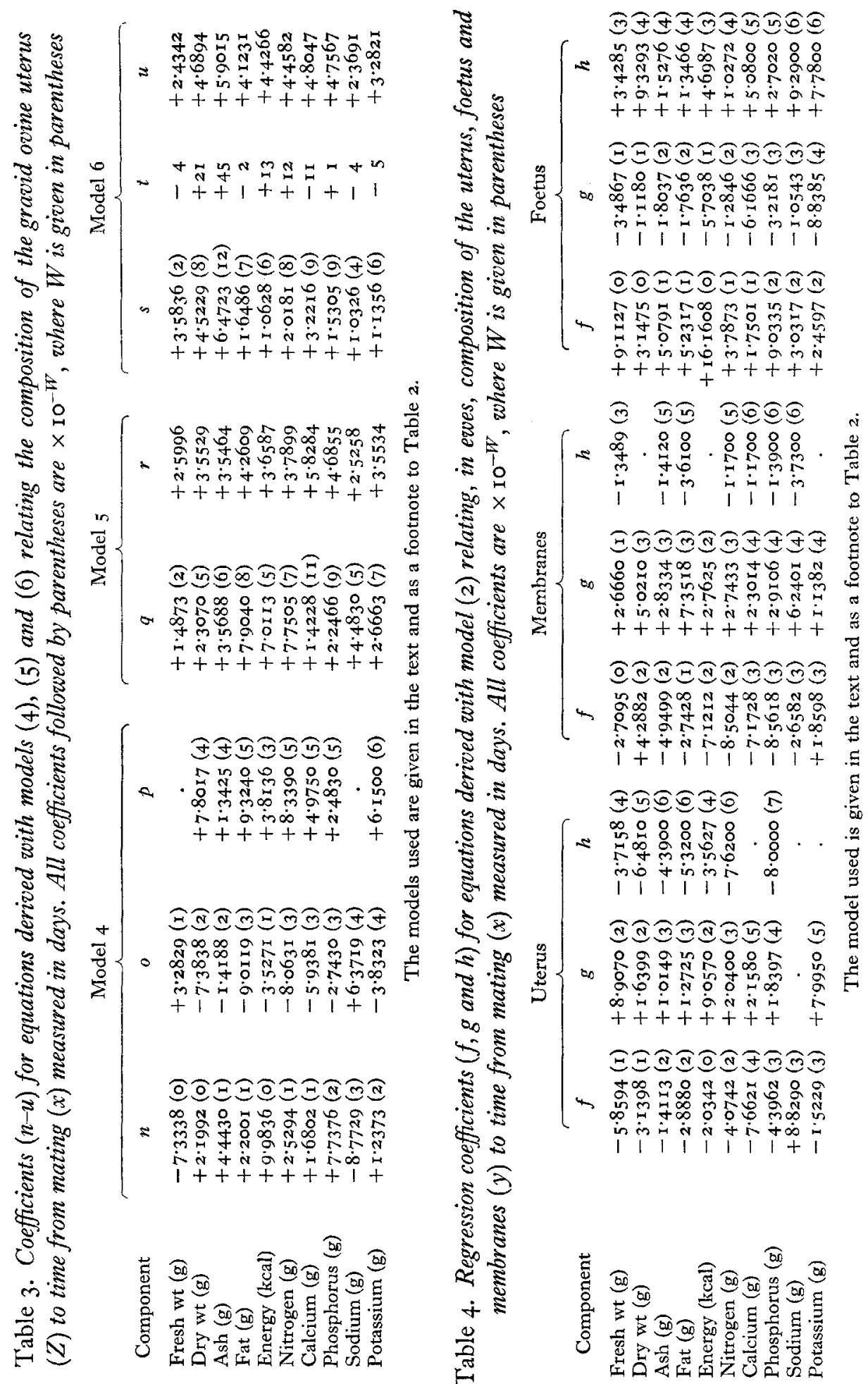
Vol. 22

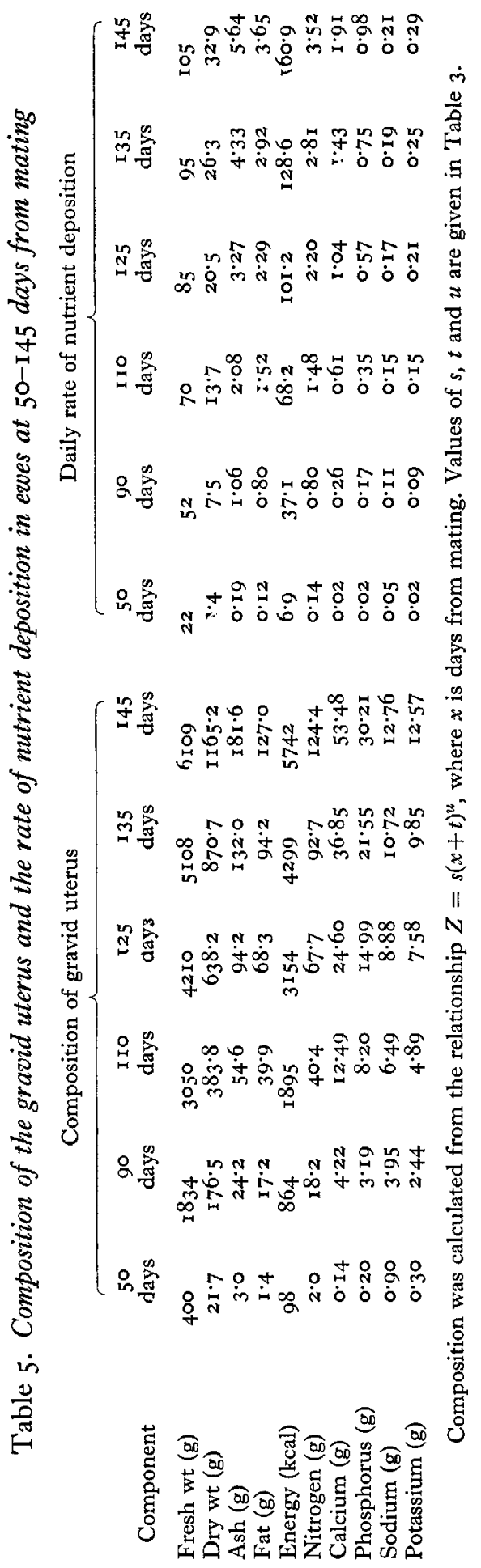


put was $23.9 \mathrm{kcal}$ per $\mathrm{kg}$ live weight per day, (3) their urinary loss when fasting was $\mathrm{r} \cdot 83 \mathrm{kcal}$ per $\mathrm{kg}$ live weight per day, and (4) the net availability of the metabolizable

Table 6. Predicted values for the composition of the foetus, uterus and membranes calculated with model (2), in ewes at 90,125 and 145 days from mating

\begin{tabular}{|c|c|c|c|c|c|c|c|c|c|}
\hline \multirow[b]{2}{*}{ Component } & \multicolumn{3}{|c|}{ Foetus } & \multicolumn{3}{|c|}{ Uterus } & \multicolumn{3}{|c|}{ Membranes } \\
\hline & $\begin{array}{c}90 \\
\text { days }\end{array}$ & $\begin{array}{c}125 \\
\text { days }\end{array}$ & $\begin{array}{c}\text { I45 } \\
\text { days }\end{array}$ & $\begin{array}{c}90 \\
\text { days }\end{array}$ & $\begin{array}{l}125 \\
\text { days }\end{array}$ & $\begin{array}{l}\text { I } 45 \\
\text { days }\end{array}$ & $\begin{array}{c}90 \\
\text { days }\end{array}$ & $\begin{array}{c}\text { I25 } \\
\text { days }\end{array}$ & $\begin{array}{l}\text { I } 45 \\
\text { days }\end{array}$ \\
\hline$v t(g)$ & 495 & 2387 & 4443 & 398 & 593 & 655 & 932 & 1192 & 1100 \\
\hline (g) & $57 \cdot 8$ & $468 \cdot 7$ & $949^{\circ} 9$ & $57 \cdot 3$ & 90.4 & $101 \cdot 7$ & $44 \cdot 5$ & $83 \cdot 8$ & I I I 8 \\
\hline & I I.O & $80 \cdot 0$ & $160 \cdot 1$ & 3.7 & $5 \cdot 5$ & $5 \cdot 9$ & $8 \cdot 2$ & 10.5 & $9 \cdot 3$ \\
\hline & $2 \cdot 4$ & $52 \cdot 8$ & $1 \pm 5.6$ & $3 \cdot 8$ & $5 \cdot 9$ & $6 \cdot 3$ & $8 \cdot 5$ & IO. I & $4 \cdot 7$ \\
\hline (kcal) & 260 & $228_{5}$ & 4675 & 291 & 465 & 523 & $2 \times 7$ & 423 & 570 \\
\hline g) & $4^{\circ} 9$ & $47^{\cdot 2}$ & $98 \cdot 0$ & $7 \cdot 3$ & I I 9 & $\mathrm{I} 3 \cdot 8$ & $6 \cdot 0$ & $9 \cdot 4$ & $9 \cdot 7$ \\
\hline & $2 \cdot 83$ & $24: 74$ & 50.59 & 0.11 & 0.24 & 0.34 & 0.37 & $0.4 \mathrm{I}$ & 0.23 \\
\hline us $(\mathrm{g})$ & $x \cdot 76$ & $13 \cdot 78$ & 27.81 & 0.51 & 0.76 & 0.79 & 0.57 & 0.76 & 0.64 \\
\hline & 0.96 & $5 \cdot 46$ & 10.55 & 0.79 & I. 10 & $I \cdot 28$ & 2.10 & $2 \cdot 13$ & $r \cdot 36$ \\
\hline $\mathrm{Im}(\mathrm{g})$ & 0.73 & $4 \cdot 46$ & $8 \cdot 70$ & $0.5 \mathrm{I}$ & $1 \cdot 06$ & $I \cdot 46$ & I.O9 & 2.01 & $2 \cdot 66$ \\
\hline
\end{tabular}

Composition (y) was calculated from relationship $y=f x+g x^{2}+h x^{3}$, where $x$ is days from mating. Values of $f, g$ and $h$ are given in Table 4 .

\section{Table 7. Calculations for deriving the metabolizable energy required per day} for pregnancy by two Merino ewes; all values are on a daily basis

\begin{tabular}{|c|c|c|c|c|c|c|c|c|}
\hline $\begin{array}{c}\text { Days } \\
\text { pregnant }\end{array}$ & $\begin{array}{c}\text { Heat } \\
\text { output } \\
\text { (kcal) }\end{array}$ & $\begin{array}{l}\text { Heat } \\
\text { output } \\
\text { for } \\
\text { pro- } \\
\text { duction } \\
\text { (kcal) }\end{array}$ & $\begin{array}{l}\text { Rate } \\
\text { of } \\
\text { energy } \\
\text { storage } \\
\text { in } \\
\text { gravid } \\
\text { uterus } \\
\text { (kcal) }\end{array}$ & $\begin{array}{c}\text { Energy } \\
\text { retention } \\
\text { (kcal) }\end{array}$ & $\begin{array}{l}\text { Extra- } \\
\text { uterine } \\
\text { storage } \\
\text { of } \\
\text { energy } \\
\text { (kcal) }\end{array}$ & $\begin{array}{c}\text { Heat } \\
\text { output } \\
\text { resulting } \\
\text { from } \\
\text { extra- } \\
\text { uterine } \\
\text { storage } \\
\text { (kcal) }\end{array}$ & $\begin{array}{c}\text { Heat } \\
\text { production } \\
\text { of } \\
\text { gestation } \\
\text { (kcal) }\end{array}$ & $\begin{array}{l}\text { Meta- } \\
\text { bolizable } \\
\text { energy } \\
\text { for } \\
\text { pregancy } \\
\text { (kcal) }\end{array}$ \\
\hline \multicolumn{9}{|c|}{ Ewe 2I } \\
\hline 90 & I 490 & 292 & 37 & 378 & $34 \mathrm{I}$ & 302 & -10 & 27 \\
\hline I IO & I $57^{\circ}$ & 372 & 68 & 298 & 230 & 204 & I68 & 236 \\
\hline 125 & I 644 & 446 & IOI & 224 & 123 & 109 & 337 & $43^{8}$ \\
\hline I35 & 1708 & 510 & 129 & 160 & $3 I$ & 27 & $48_{3}$ & 612 \\
\hline 145 & 1790 & 592 & $16 r$ & 78 & -83 & -20 & 612 & 773 \\
\hline \multicolumn{9}{|c|}{ Ewe 23} \\
\hline 90 & 1490 & 382 & 37 & 430 & 393 & 349 & 33 & 70 \\
\hline I10 & 1570 & 462 & 68 & $35^{\circ}$ & 282 & 250 & 212 & 280 \\
\hline I 25 & I644 & 536 & IOI & 276 & 175 & 155 & 381 & 482 \\
\hline I35 & 1708 & 600 & 129 & 212 & $8_{3}$ & 74 & 526 & 655 \\
\hline 145 & $\mathrm{r} 790$ & 682 & 161 & 130 & $-3 I$ & -7 & 689 & 850 \\
\hline
\end{tabular}

Daily heat output was taken from Graham ( $1964 a$ ).

Heat output for production $=$ daily heat production -heat production of non-pregnant sheep at maintenance. Rate of energy storage in gravid uterus was taken from Table 5. Energy retention was calculated as the difference between metabolizable energy intake and daily heat output. Extra-uterine storage of energy = energy retention-energy storage in gravid uterus. Heat output from extra-uterine storage $=$ extra-uterine storage of energy $\times 0.887$ when extra-uterine storage is positive and $\times 0.235$ when negative. Heat production of gestation $=$ heat output for production - heat output for extrauterine storage. Metabolizable energy for pregnancy $=$ heat production of gestation + energy storage in gravid uterus. 
energy of the diet below maintenance was $8 \mathrm{r} \%$. The heat productions of these sheep at $90, \mathrm{I} 1 \mathrm{O}, \mathrm{I} 25, \mathrm{I} 35$ and $\mathrm{I} 45$ days of pregnancy were taken from Graham's results and the heat productions of the ewes at maintenance were deducted. The results are given in column 3 of Table 7 . In columns 4 and 5 the rate of energy storage per day in the gravid uterus calculated from an equation derived with model (6) and the energy retention of the ewes are given. Energy retention was calculated as the difference between the daily metabolizable energy intake ( $1868 \mathrm{kcal}$ for ewe 21 and $1920 \mathrm{kcal}$ for ewe 23) and the daily heat production (column 2). Energy storage in the extrauterine tissue was calculated as the difference between energy retention (column 5) and energy stored in the conceptus (column 4). The heat production associated with energy storage in the extra-uterine tissues (column 7) was derived by multiplying positive values in column 6 by $(100-53) / 53$, since $53 \%$ was the net availability of the

Table 8. Nutrients utilized daily for pregnancy, at 90-145 days after mating, by a Merino ewe carrying a single foetus

\begin{tabular}{|c|c|c|c|c|c|c|}
\hline \multirow[b]{2}{*}{ Nutrient } & \multirow[b]{2}{*}{ Units } & \multicolumn{5}{|c|}{ Days } \\
\hline & & 90 & 110 & 125 & 135 & $\mathrm{x} 45$ \\
\hline Energy* & Metabolizable (kcal) & 49 & 258 & 460 & 634 & 812 \\
\hline Nitrogen & Available (g) & $1 \cdot 2$ & $2 \cdot 3$ & $3 \cdot 4$ & 43 & $5 \cdot 4$ \\
\hline Calcium & $\mathrm{g}$ & 0.58 & $x \cdot 35$ & $2 \cdot 3^{I}$ & $3 \cdot 17$ & $4 \cdot 24$ \\
\hline Phosphorus $\dagger$ & $\mathrm{g}$ & 0.28 & 0.58 & 0.95 & $I \cdot 25$ & I. 64 \\
\hline Sodium & $\mathrm{g}$ & O.II & 0.15 & 0.17 & 0.19 & 0.21 \\
\hline Potassium & $\mathrm{g}$ & 0.09 & $0 . \times 5$ & $0.2 \pi$ & 0.25 & 0.29 \\
\hline
\end{tabular}

* Values for ewes 21 and 23 of Graham (1964a) have been averaged to provide these estimates.

+ Calculated by means of factor of $I \cdot 67$.

metabolizable energy of the diet above maintenance for a non-pregnant sheep (Graham, I $964 b$ ), and negative values by $0 \cdot 235$ (or $19 / 8 \mathrm{r}$ ). This assumes that metabolizable energy is utilized for maternal live-weight gain with equal efficiency by pregnant and non-pregnant ewes. The heat production of gestation was taken as the difference between the values in columns 3 and 7 , and the metabolizable energy utilized for pregnancy as the sum of the heat production for gestation and the daily rate of energy deposition in the conceptus.

The Agricultural Research Council (1965) have calculated nutrient requirements for pregnancy from the product of the rate of nutrient deposition in the conceptus and the reciprocal of the availability of the nutrients for pregnancy expressed as a decimal; the values taken for this reciprocal were $\mathrm{I} \cdot 54$ for $\mathrm{N}, 2 \cdot 22$ for $\mathrm{Ca}, \mathrm{I} \cdot 25^{-\mathrm{I}} \cdot 67$ for $\mathrm{P}$ depending on the age of the sheep, and $\mathrm{I} \cdot \circ$ for $\mathrm{Na}$ and $\mathrm{K}$. These values have been used to derive the estimates of the nutrients utilized for pregnancy in Table 8 .

\section{DISCUSSION}

The method used provides an estimate of the nutrients utilized for pregnancy at a specific level of nutrition. The estimates given in Table 8 were derived with pregnant ewes which maintained live weight without conceptus approximately constant through- 
out pregnancy and which gave birth to a foetus weighing $4.4 \mathrm{~kg}$ on the 145 th day of pregnancy. It is likely that the estimates would be increased if a heavier lamb had been produced by feeding the ewe at a higher plane of nutrition, and this might be desirable for economic or husbandry reasons. In these circumstances much of the additional feed is utilized for live-weight gain by the ewe, and this would not be included in the estimates given in Table 8 .

There is little information in the literature with which to compare our analyses of the composition of the gravid uterus at various stages of pregnancy. The gross energy and $\mathrm{N}$ content of four Merino lambs were determined at birth by Graham (1964a). His values ranged from $\mathrm{I} \cdot 03$ to $\mathrm{I} \cdot \mathrm{I} g \mathrm{kcal}$ per $\mathrm{g}$ fresh weight and from 2.24 to $2.57 \mathrm{~g}$ $\mathrm{N}$ per $100 \mathrm{~g}$ fresh weight. In this study the corresponding values for the foetus at $\mathrm{I} 45$ days were $\mathrm{I} \cdot 05 \mathrm{kcal}$ and $2 \cdot 2 \mathrm{I} \mathrm{g} \mathrm{N}$. Duncan (1958) has summarized $\mathrm{Ca}$ and $\mathrm{P}$ analyses of newly born lambs. Merino lambs of unknown weight contained $27-35 \mathrm{~g} \mathrm{Ca}$ and I 8-24 $\mathrm{g} \mathrm{P}$. Values for Cheviot lambs ranged from 28 to $77 \mathrm{~g} \mathrm{Ca}$ and from 15 to $40 \mathrm{~g} \mathrm{P}$. In this study the foetus at $\mathrm{x} 45$ days was estimated to contain $5 \circ \cdot 6 \mathrm{~g} \mathrm{Ca}$ and $27.8 \mathrm{~g} \mathrm{P}$. Values of $2.0 \mathrm{~g} \mathrm{Na}$ and $\mathrm{K}$ per $\mathrm{kg}$ fresh weight for the gravid uterus throughout pregnancy were accepted by the Agricultural Research Council (I965); the corresponding values in this study at $\mathrm{I} I 0$ and $\mathrm{I} 45$ days were $2 \cdot 12$ and $2.08 \mathrm{~g} \mathrm{Na}$ and $\mathrm{I} \cdot 60$ and $2 \cdot 05 \mathrm{~g} \mathrm{~K}$.

Our estimates of the nutrients utilized for pregnancy are subject to errors in the estimation of nutrient retention and of the availability of the nutrients for pregnancy. The latter is likely to be the more important, particularly with nutrients of low availability such as $\mathrm{Ca}$. Changes in the maternal body excluding those occurring in the gravid uterus have been ignored in calculating the nutrient requirements for gestation, but changes in plasma volume (Barcroft, Kennedy \& Mason, 1939), mammary glands and possibly in the liver and alimentary tract are known to occur. This introduces bias into the estimates given in Table 8, but the error is probably small (Agricultural Research Council, 1965). Our calculations of energy utilization are also open to criticism. It was assumed that energy was stored in extra-uterine tissue with similar efficiencies by both pregnant and non-pregnant sheep. There is no information by which this assumption may be justified. The findings of Armstrong \& Blaxter (1965) indicate that metabolizable energy was stored more efficiently by the lactating than by the non-lactating goat and the pregnant sheep may be more efficient or less efficient than the non-pregnant animal. When more detailed information is available, it may be necessary to amend the calculations given in Table 7 .

Comparison of the different estimates of the nutrients utilized for pregnancy is difficult because many authors include an allowance for the live-weight gain of the ewe. In addition, the units used to express nutrient intake differ between authors, and the weight of the lamb at birth, which will affect the estimate, differs with breed and plane of nutrition of the ewe. For example, the National Research Council (I957) estimates provide for an increased energy requirement of I $148 \mathrm{kcal}$ metabolizable energy per day during the last 6 weeks of gestation. However, this estimate allows for a gain in live weight of $0.37 \mathrm{lb}$ daily and as a result the National Research Council (1957) estimates are substantially larger than our values, which are $258 \mathrm{kcal}$ at the I I oth day of pregnancy 
rising to $812 \mathrm{kcal}$ at the $145^{\text {th }}$ day. Russel, Doney \& Reid ( 1967 ) calculated requirements for pregnancy from the nutrient intake necessary to maintain plasma free fatty acid levels below $750 \mu$-equiv/1. or ketone bodies below $8 \mathrm{mg}$ acetone/ $100 \mathrm{ml}$ plasma. They estimated that $400 \mathrm{kcal}$ metabolizable energy per $\mathrm{kg}$ of foetus per day were required for Scottish Blackface ewes during the final ro days of pregnancy, which is equivalent to $\mathrm{I} 760 \mathrm{kcal}$ metabolizable energy for our sheep. This value is approximately double the estimate derived in the present study.

The estimates of $\mathrm{N}$ utilization derived in the present study were smaller than those proposed by the Agricultural Research Council (1965), which increase from $2 \cdot 2 \mathrm{~g}$ available $\mathrm{N}$ in the $4^{\text {th }}$ month of pregnancy to $8.0 \mathrm{~g}$ in the $5^{\text {th }}$ month. The discrepancy can in part be attributed to the smaller foetuses of the Merino sheep. Our values for the $\mathrm{Ca}$ and $\mathrm{P}$ requirements are in good agreement with those of the Agricultural Research Council (I965).

\section{REFERENCES}

Agricultural Research Council (1965). The Nutrient Requirements of Farm Livestock. No. 2. Ruminants. London: Agricultural Research Council.

Armstrong, D. G. \& Blaxter, K. L. (1965). Publs Eur. Ass. Anim. Prod. no. I I, p. 59.

Barcroft, J., Kennedy, J. A. \& Mason, M. F. (1939). F. Physiol., Lond. 95, 159.

Cloete, J. H. L. (1939), Onderstepoort F. vet. Sci. 13, 417.

Duncan, D. L. (1958). Nutr. Abstr. Rev. 28, 695.

Fogg, D. N. \& Wilkinson, N. T. (1958). Analyst, Lond. 83, 406.

Graham, N. McC. (1964a). Aust. F. agric. Res. 15, 127.

Graham, N. McC. (I 964b). Aust, F. agric. Res. I5, roo.

Jakobsen, P. E. (I957). Beretn. Forsogslab. Copenh. no. 299.

MacDowell, E. C. \& Allen, E. (1927). Proc. Soc. exp. Biol. Med. 24, 672.

Mitchell, H. H. (1962). Comparative Nutrition of Man and Domestic Animals. Vol. I. New York and London: Academic Press Inc.

Mitchell, H. H., Carroll, W. E., Hamilton, T. S. \& Hunt, G. E. (I93 I). Bull. Ill. agric. Exp. Stn no. 375.

National Research Council (1957). Publs natn. Res. Coun., Wash. no. 504.

Radford, H. M., Watson, R. H. \& Wood, G. F. (1960). Aust. vet. F. 36, 57.

Russel, A. J. F., Doney, J. M. \& Reid, R. L. (1967). F. agric. Sci., Camb. 68, 359.

Wallace, L. R. (1948). F. agric. Sci., Camb. 38, 243 . 